\title{
Recent advances in control technologies for non-point source pollution with nitrogen and phosphorous from agricultural runoff: current practices and future prospects
}

\author{
Yinfeng Xia ${ }^{1,2}$, Ming Zhang ${ }^{3}$, Daniel C. W. Tsang ${ }^{4}$, Nan Geng ${ }^{1,2}$, Debao Lu ${ }^{1,2}$, Lifang Zhu', \\ Avanthi Deshani Igalavithana ${ }^{2}$, Pavani Dulanja Dissanayake ${ }^{2}$, Jörg Rinklebe ${ }^{5,6}$, Xiao Yang ${ }^{2}$ and Yong Sik Ok ${ }^{2 *}$
}

\begin{abstract}
Eutrophication of natural water is a universal problem. Nitrogen $(\mathrm{N})$ and phosphorus $(\mathrm{P})$ from agricultural runoff are the main sources of nutrient input, provided that emissions from industrial point sources (IPS) are under control. Therefore, it is of great environmental importance to reduce pollution associated with agricultural runoff as a means of regulating eutrophication levels in natural water. Numerous methods proposed for treating agricultural runoff can be classified into three categories: source control, process control, and end treatment. In this review, major technologies for $\mathrm{N}$ and $\mathrm{P}$ control from agricultural runoff are summarized along with discussion of newly proposed technologies such as biochar biomimetics and microbial catalyst. Because agricultural runoff (from farmlands to receiving waters) is a complicated pollution process, it is difficult to regulate the nutrients discharged via such process. This review will thus offer a comprehensive understanding on the overall process of agricultural runoff and eutrophication to help establish control strategies against highly complicated agricultural non-point sources.
\end{abstract}

Keywords: Eutrophication, Phytoremediation, Charcoal, Black carbon, Soil organic matter, Water and wastewater treatment, Sustainable development goals

\section{Introduction}

Water is a very important resource for human survival and development. Environmental pollution is the greatest challenge in maintaining safe water sources [1-3]. In recent decades, various technologies were developed to treat industrial effluent and domestic sewage, among others [4-7].

Agricultural non-point source pollution has long been considered an important factor affecting the level of eutrophication [8-10]. For example, agricultural nonpoint source pollution is estimated to be responsible for

\footnotetext{
*Correspondence: yongsikok@korea.ac.kr

${ }^{2}$ Korea Biochar Research Center \& Division of Environmental Science and Ecological Engineering, Korea University, Seoul, Republic of Korea Full list of author information is available at the end of the article
}

52 and $54 \%$ of the total loading of nitrogen (TN) and phosphorus (TP), respectively in Taihu Lake Basin, China [11]. Likewise, they are also found to represent $24 \%$ and $71 \%$, respectively in Italy [12]. In USA, agricultural nonpoint source pollution is considered the dominant source of nutrients in lakes and streams [13]. Appropriate management of agricultural runoff and animal waste is a large concern for the U.S. Environmental Protection Agency (USEPA) and U.S. Department of Agriculture (USDA).

Agricultural runoff is the surface runoff from farmland outflow, which comes from the farmland's surplus water. Its main sources of excess water are from irrigation and rainfall [14]. Agricultural runoff has complex pollutant compositions including nitrates, ammonium, phosphorus compounds, heavy metals, and persistent organic pollutants. $\mathrm{N}$ and $\mathrm{P}$, being essential elements in 
amino acids and genetic material, respectively, are vital to the growth of aquatic plants as the key limiting nutrients during eutrophication [15].

Anthropogenic eutrophication has become the primary problem as it is often recognized to have strong potentials to affect the health and security of aquatic ecosystems in the world. The large "cyanobacteria mat" in Taihu Lake (Fig. 1) caused the closing of a drinking water plant in Wuxi, leading to a crisis affecting millions of people $[16,17]$. At the same time, continuous input of heavy metals and persistent organic pollutants (POPs) from agricultural runoffs can easily accumulate in organisms to pose various health risks (e.g., pollution of drinking water). Therefore, it is of considerable interest to adequately decrease agricultural non-point source pollution to control eutrophication in lakes and rivers, to protect the water environment, and to secure drinking water quality.

There are three main control strategies for agricultural runoff pollution: source control, process control, and end treatment. Source control works to reduce the application of $\mathrm{N}$ and $\mathrm{P}$ as well as leaching, such as conservation tillage, fertilization management, and water-saving irrigation [18-20]. Process control aims to eliminate the pollutants by using the space and time of agricultural runoffs from the field to the receiving water, such as ecological ditches [21]. They are usually set in the agricultural ditches. End treatment is the last choice to avoid the damage of the receiving water, if the pollutants does not fall below the safe value [22]. The large storage capacity provides more time for the treatment of agricultural runoffs. Although each approach is based on different principles, they serve to control agricultural runoff pollution to varying degrees. It is difficult to find efforts to integrate the diverse treatment options from source to end. In this

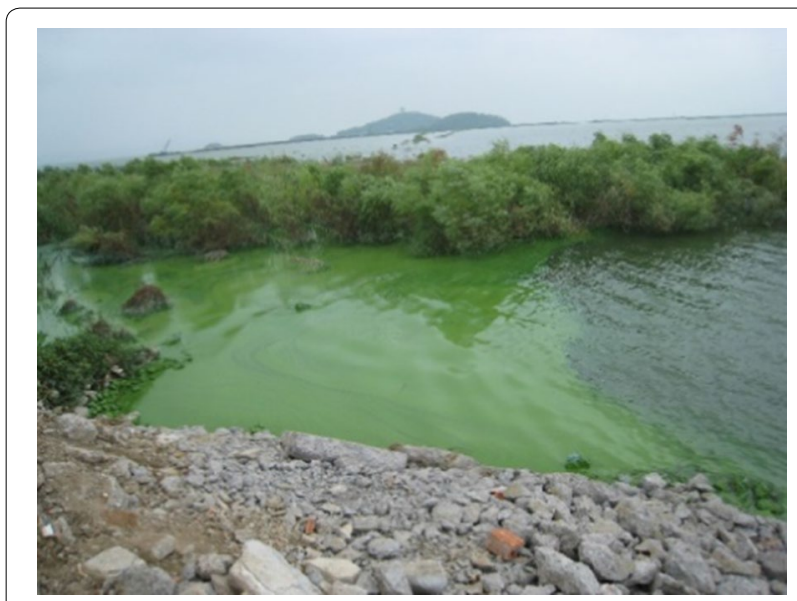

Fig. 1 Cyanobacteria outbreak in Taihu Lake, China review, we highlight current mainstream technologies along with some promising alternatives. A scenario analysis based on the reference data was also made to provide a comprehensive understanding of the current control techniques for agricultural runoff and their roles in effective control of agricultural runoff.

\section{Pollution status of agricultural runoff}

Agriculture supports the construction and development of a national economy. It is of particular importance to the most populated countries, such as China, India, and Indonesia [23]. Due to the great demand for food, the use of chemical fertilizers and pesticides has become indispensable over the past decades [24]. The N and P fertilizers have been used most widely in the world. According to statistical data from Food and Agriculture Organization of the United Nations (FAO, Table 1), as of 2015 the world's average use of $\mathrm{N}$ fertilizer per cropland area has reached $68.6 \mathrm{~kg} / \mathrm{ha}$, and $30.1 \mathrm{~kg} / \mathrm{ha}$ for P. The USA is still increasing their use of fertilizers. Moreover, China is the largest producer and consumer of fertilizers. Overuse of chemical fertilizers leads to various environmental problems including surface water eutrophication, N-related greenhouse gas emissions, and groundwater pollution [25-27]. Although the application of fertilizer is made to the farmland, the transport of excess $\mathrm{N}$ and $\mathrm{P}$ takes place by surface water runoff after rainfall and irrigation events. As shown in Fig. 2, the $\mathrm{N}$ and $\mathrm{P}$ migration process increases the complexity of the whole system, while providing temporal and spatial conditions for effective remediation. As the main component of an agricultural irrigation system, ditches can act as the major pathway of farmland surface runoff. Since agricultural runoff undergoes a certain amount of migration time before discharging to the receiving water, ditches can be an ideal place for controlling on $\mathrm{N}$ and $\mathrm{P}$ [28].

The diffusivity of $\mathrm{N}$ and $\mathrm{P}$ differs greatly in soils. Cookson et al. have reported that the diffusion coefficient of $\mathrm{H}_{2} \mathrm{PO}_{4}{ }^{-}$in soils was only one thousandth of that of $\mathrm{NO}_{3}{ }^{-}$ to affect the rate of runoff losses in N and P [29]. In a cropland fertilized with $196 \mathrm{~kg} \mathrm{~N} \mathrm{ha}^{-1}$ year $^{-1}$ and $87 \mathrm{~kg} \mathrm{P}$ $\mathrm{ha}^{-1}$ year $^{-1}, \mathrm{~N}$ and $\mathrm{P}$ fertilizer runoff loss rates were $9.5 \%$ and $3.3 \%$, respectively [30]. In contrast, in paddy soils fertilized with $210 \mathrm{~kg} \mathrm{~N} \mathrm{ha}^{-1}$ year $^{-1}$ and $36 \mathrm{~kg} \mathrm{P} \mathrm{ha}^{-1}$ year $^{-1}$, $\mathrm{N}$ and $\mathrm{P}$ fertilizer runoff loss rates were $5.9 \%$ and $0.52 \%$, respectively [31]. In this case, the $\mathrm{N}$ and $\mathrm{P}$ discharge rates were estimated as 12.39 and $0.18 \mathrm{~kg} \mathrm{ha}^{-1}$ year $^{-1}$, respectively. Although the loss load of nutrients varies little from year to year, it varies greatly from month to month. For instance, the highest $\mathrm{N}$ and $\mathrm{P}$ loss concentrations took place over April, June, July, and August in China, which correspond to the high-risk eutrophication period [32]. The unevenness of time distribution of loss load 
Table 1 Fertilizer application levels worldwide and by country (data from FAO)

\begin{tabular}{|c|c|c|c|c|c|c|c|}
\hline \multirow[t]{2}{*}{ Number } & \multirow[t]{2}{*}{ Region } & \multicolumn{3}{|c|}{$\mathrm{N}$ fertilizer application level (kg/ha/year) } & \multicolumn{3}{|c|}{ P fertilizer application level (kg/ha/year) } \\
\hline & & 2005 & 2010 & 2015 & 2005 & 2010 & 2015 \\
\hline 1 & World & 57.55 & 65.13 & 68.61 & 24.98 & 27.75 & 30.10 \\
\hline 2 & USA & 65.63 & 69.75 & 77.46 & 24.56 & 21.21 & 26.82 \\
\hline 3 & China & 213.5 & 241.92 & 228.48 & 94.73 & 115.27 & 116.4 \\
\hline 4 & India & 74.99 & 97.21 & 102.51 & 30.71 & 48.43 & 41.18 \\
\hline 5 & Indonesia & 59.05 & 62.43 & 61.27 & 8.03 & 11.19 & 17.11 \\
\hline 6 & Japan & 117.98 & 97.86 & 79.87 & 130.25 & 92.38 & 76.78 \\
\hline 7 & Netherlands & 244.35 & 205.82 & 203.11 & 42.55 & 29.02 & 12.22 \\
\hline 8 & Spain & 51.77 & 54.65 & 62.54 & 28.77 & 19.55 & 24.16 \\
\hline 9 & Thailand & 55.43 & 79.21 & 80.74 & 17.12 & 24.11 & 16.39 \\
\hline 10 & Argentina & 18.89 & 19.79 & 14.52 & 15.14 & 17.54 & 11.62 \\
\hline 11 & Australia & 19.14 & 22.85 & 28.04 & 20.94 & 19.17 & 19.98 \\
\hline 12 & Brazil & 27.11 & 47.36 & 44.23 & 37.57 & 43.58 & 52.65 \\
\hline
\end{tabular}

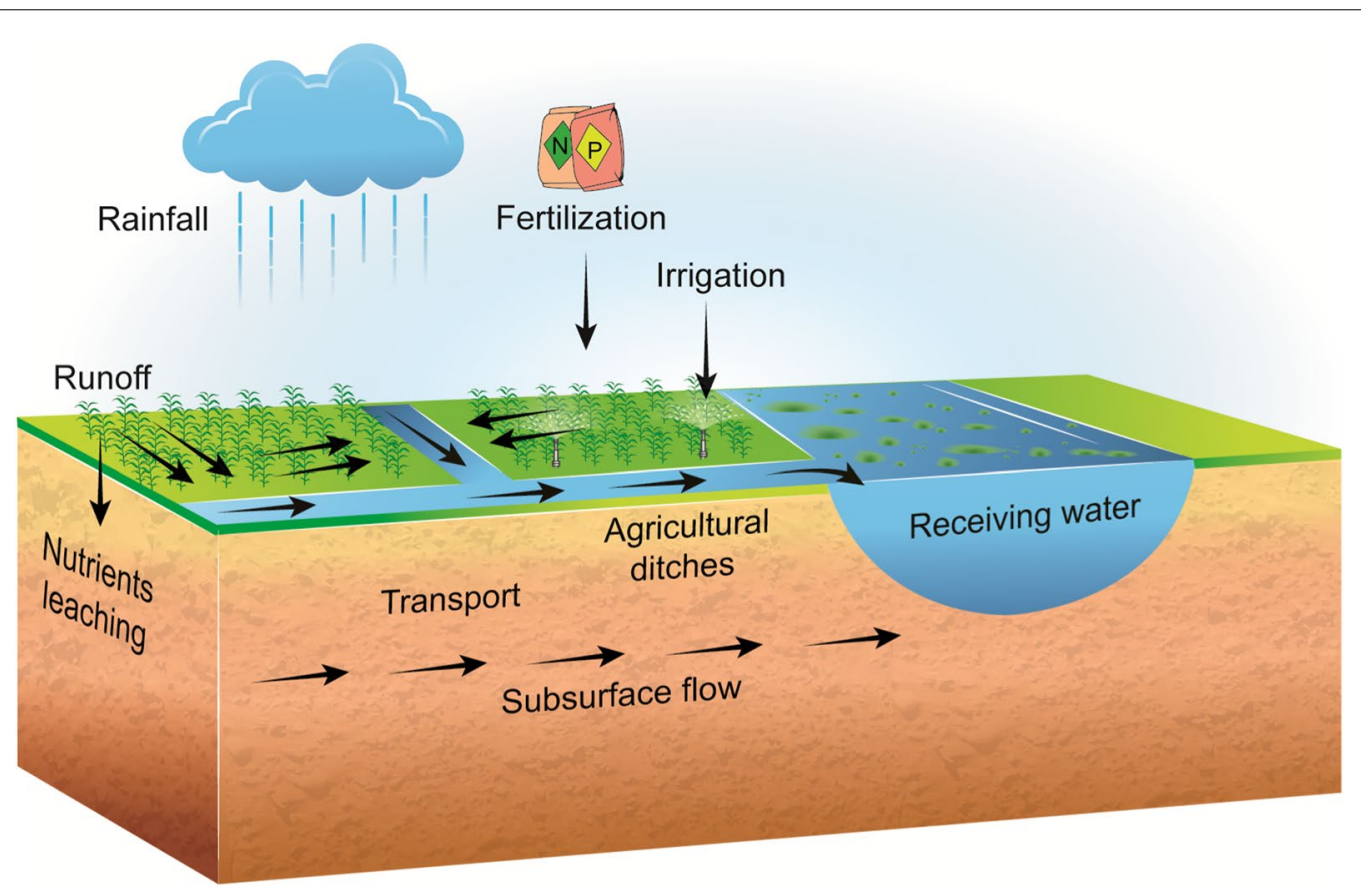

Fig. 2 Schematic diagram of agricultural runoff generation and control

greatly increases the difficulty of controlling nutrient loss from agricultural runoff.

As a major form of non-point source agricultural pollution, continuous $\mathrm{N}$ and $\mathrm{P}$ input leads to their accumulation in the receiving water. Excessive $\mathrm{N}$ and $\mathrm{P}$ accumulation causes various problems such as algal blooms, water degradation, fish kills, and loss of biodiversity [33]. Due to the lack of effective control on agricultural non-point pollution, $\mathrm{N}$ and $\mathrm{P}$ pollution has become a global problem. In case of USA, over-enrichment issues of $\mathrm{N}$ and $\mathrm{P}$ were observed from about $50 \%$ of impaired lake areas and $60 \%$ of impaired river reaches [34]. In China, over half of the major lakes are eutrophic while nearly three quarters are continuously deteriorating [35]. Even in Canada, the deterioration of lake Winnipeg is also attributed to excessive $\mathrm{N}$ and $\mathrm{P}$ nutrient enrichment [36]. Therefore, controlling $\mathrm{N}$ and $\mathrm{P}$ from agricultural runoff is urgent. 


\section{Research progress in source control technologies}

Dissolved pesticides, nutrients, and sediments in agricultural runoff cause various problems, including persistent organic translocation, nutrient loss, and soil erosion [37]. Reasonable tillage practices can significantly improve surface roughness and reduce surface runoff, thus reducing runoff emissions and pollution load at the source. As a food staple for $1 / 3$ of the world's population, rice is planted over an area of more than 164 million hectares. Rice requires a great deal of water, which leads to massive agricultural runoff [38]. The dissolved N, P and sediments create a huge pollution load on the surrounding waters [39-41].

\section{Conservation tillage}

Although, tillage inevitably disturbs the soil surface, conservation tillage methods (such as reduced tillage and no-tillage) play significant roles in protecting soil from erosion [42]. In addition, conservation tillage improves soil structure and increase organic matter content, which can increase the infiltration to runoff ratio and reduce evaporation $[43,44]$. Reduced tillage and notillage are both effective methods of conservation tillage. For example, Clausen et al. studied tillage effects on runoff for croplands in Vermont, USA, and found that reduced tillage reduced runoff by $64 \%$ [45]. Liang et al. reported that runoff volume from rice-planting watersheds was reduced by $25.9 \%$ using no-tillage techniques [46]. Reduced tillage and no-tillage reduce the intensity of tillage practices as well as the impact of rain by the protection of soil surface using crop residues. In recent years, land covers and soil amendments such as biochar, which enhance the soil structure and porosity, are used to protect the soil $[47,48]$. Won et al. used rice straw, polyacrylamide, and gypsum to treat with Chinese cabbage filed, which resulted in reduction of suspended solids and of total nitrogen (TN) by $86.6 \%$ and $34.7 \%$, respectively [49]. Lee et al. have studied the effects of soil amendments on soil loss [50]. Accordingly, the field soils amended with biochar and polyacrylamide reduced soil loss by $70.4 \%$ in a $33 \mathrm{~mm}$ day $^{-1}$ natural rainfall, while there was no difference in runoff. Lee et al. found that field soils treated with $4 \%$ wood biochar significantly decreased runoff by $16.8 \%$ and inorganic $\mathrm{N}$ by $41.8 \%$ [51]. Biochar is often used in soil remediation, and it also has great potential in agricultural runoff control. The effects of biochar on soil structure and nutrient fixation are worth further studies $[52,53]$.

\section{Rotation tillage}

Conservation tillage is effective for reducing dissolved $\mathrm{N}$ in the runoff [54]. However, conservation tillage practices will inevitably lead to soil compaction during long-term operation, which will lead to $\mathrm{P}$ accumulation on the soil surface, and as a consequence, an increase in the runoff loss of P. Tiessen et al. reported that conservation tillage in the Canadian prairies reduced the TN concentration by $41 \%$ while the total phosphorus (TP) increased by $42 \%$ [36]. Rotation tillage is another choice to control nutrients loss in agricultural runoff. Liu et al. converted conservation tillage to rotation tillage and found that rotation tillage was a better option to decrease various types of $\mathrm{P}$ (e.g., either contained in surface soil or released from crop residue) as well as runoff duration [54]. As a result, total dissolved P (TDP) and TP decreased by $46 \%$ and $38 \%$, respectively. It is because tillage practices would alleviate soil compaction and decrease $\mathrm{P}$ accumulation in surface soil. Crop residues in conservation tillage would capture more water that leads to greater runoff duration time. Therefore, rotation tillage could shorten the contact time between crop residues and surface runoff that reduces the $P$ released from crop residues. Daverede et al. compared P runoff after no-tillage and chisel plow farming practices and found that the latter could reduce the dissolved reactive P load by $60 \%$ [55]. Therefore, the selection of tillage practice should be based on local climatic conditions, soil conditions, crops, and dominant eutrophication nutrients.

\section{Fertilization management}

Fertilization management is another effective source control method that has been used widely [56, 57]. Fertilizers containing $\mathrm{N}$ and $\mathrm{P}$ are commonly used in the agricultural industry. $\mathrm{N}$-fertilizer efficiency varies from crop to crop. For example, mean $\mathrm{N}$-fertilizer efficiencies of maize, wheat, and rice are $37 \%, 18 \%$, and $31 \%$, respectively [58]. In order to fully reflect the global nitrogen use efficiency (NUE), Table 2 listed the world fertilizer $\mathrm{N}$ consumption for cereals, $\mathrm{N}$ removal in cereals, and estimated nitrogen use efficiency. The estimated NUE is $36 \%$. Once surface runoff is formed, excessive $\mathrm{N}$ and $\mathrm{P}$ would flow to the receiving water. Therefore, it is critical to deliberately manage fertilizer application. One example of fertilization management is deep placement of fertilizers to lower the risk of discharging $\mathrm{N}$ into a body of water. In the Taihu Lake region, it was found that using urea deep placement lowered $\mathrm{N}$ loss by $50 \%$ in the paddy field [59]. Fertilizer band placement and hole placement can reduce total $\mathrm{N}$ loss by $63.6 \%$ and $77 \%$, respectively, and total P loss by $42.8 \%$ and $53.8 \%$, respectively $[60,61]$. This is because band placement can reduce contact with soil microorganisms and slow the nitrification process. Zeng et al. studied the impact of fertilization depth on TN loss [62]. These authors found that a $20 \mathrm{~cm}$ fertilization depth reduced $\mathrm{TN}$ and $\mathrm{TP}$ by $36.2 \%$ and $31.4 \%$, respectively 
Table 2 World fertilizer $\mathbf{N}$ consumption, cereal production, and $\mathbf{N}$ use efficiency

\begin{tabular}{|c|c|c|}
\hline Commodities and computations & Amount/ton & Variable \\
\hline \multicolumn{3}{|c|}{ World fertilizer N consumption, 2015 (FAOSTAT) } \\
\hline Total & $108,699,171$ & \\
\hline Cereal $^{\mathrm{a}}$ & $65,219,502$ & C \\
\hline \multicolumn{3}{|l|}{ World cereal production, 2015 (FAOSTAT) } \\
\hline Barley & $147,413,603$ & \\
\hline Maize & $1,052,097,073$ & \\
\hline Millet & $28,218,225$ & \\
\hline Oats & $23,328,079$ & \\
\hline Rice & $745,337,946$ & \\
\hline Rye & $13,755,752$ & \\
\hline Sorghum & $66,006,062$ & \\
\hline Wheat & $751,863,360$ & \\
\hline Total & $2,828,020,100$ & $\mathrm{P}$ \\
\hline \multicolumn{3}{|c|}{ World cereal grain N removal, 2015 (Fujihara et al. 2008) } \\
\hline Barley $(N=21.4 \mathrm{~g} / \mathrm{kg})$ & $3,154,651$ & \\
\hline Maize $(N=13.1 \mathrm{~g} / \mathrm{kg})$ & $13,782,472$ & \\
\hline Millet $(N=20.1 \mathrm{~g} / \mathrm{kg})$ & 567,186 & \\
\hline Oats $(N=19.1 \mathrm{~g} / \mathrm{kg})$ & 445,566 & \\
\hline Rice $(N=10.5 \mathrm{~g} / \mathrm{kg})$ & $7,826,048$ & \\
\hline Rye $(N=16.3 \mathrm{~g} / \mathrm{kg})$ & 224,218 & \\
\hline Sorghum $(N=19.9 \mathrm{~g} / \mathrm{kg})$ & $1,313,521$ & \\
\hline Wheat $(N=26.2 \mathrm{~g} / \mathrm{kg})$ & $19,698,820$ & \\
\hline Total & $47,012,482$ & $\mathrm{~N}$ \\
\hline $\begin{array}{l}\text { Cereal grain N from soil and rainfall, } 2015^{c} \\
\text { Nitrogen use efficiency } \\
N U E=[(N-S) / C] \times 100=36 \%\end{array}$ & $23,506,241$ & S \\
\hline
\end{tabular}

a Fertilizer consumption of cereals calculated from average fertilizer application and cereal acreage in the world

b Cereal grain $\mathrm{N}$ values obtained from the report by Fujihara et al. [110]

c Cereal grain $\mathrm{N}$ from soil and rainfall $=\mathrm{N} \times 0.5$ [111]

compared to surface fertilization. Controlled-release of fertilizer is another choice that can lead to slow release of $\mathrm{N}$ and $\mathrm{P}$ to be adapted to the rate of crop growth while improving nutrient utilization efficiency [63]. Tan et al. have studied the effect of fertilization treatment on $\mathrm{N}$ loss in a wheat-maize rotation system [64]. Accordingly, the results indicated that controlled-release $\mathrm{N}$ fertilizer performed best in reducing inorganic $\mathrm{N}$ concentration in runoff. Controlled-release $\mathrm{P}$ fertilizer can reduce $\mathrm{P}$ loss by $62 \%$ in paddy systems and by $33 \%$ loss in corn systems [65]. Optimization of fertilizer timing and application rate is also important variables to control nutrient loss [66]. Because the losses show seasonal characteristics, with higher nutrient loading in summer and autumn. As for rainfall process, nitrate- $\mathrm{N}$ loss increased gradually along with ammonia-N loss decreased. Based on these characteristics, model-based analysis has also been proposed for long-term effects of fertilization management [67].

\section{Water-saving irrigation}

Heavy precipitation and field drainage systems can drive surface runoff. During the rice growing season, which is coupled with the rainy season, surface runoff accounts for $86 \%$ of cumulative $\mathrm{N}$ losses [68]. This is because conventional flooding irrigation (CFI) keeps a high floodwater level in the fields. Water-saving irrigation (WSI) techniques could significantly reduce floodwater levels, improving the buffering capacity of the fields to help reduce runoff and nutrient losses. Furthermore, WSI enhanced root growth with getting more grain yield compared to CFI [69]. Alternate Wetting and Drying (AWD) irrigation has also been employed widely to reduce water inputs and enhance water use efficiency in the rice cropping systems [70-72]. The AWD irrigation was seen to reduce surface runoff by $30.2-36.7 \%$ compared to conventional practices [73]. The concentrations of nutrients, however, do not decrease with the decrease of surface runoff if AWD is applied alone. Because the contact time between water and soils will not decreased. Thus, it is better to integrate irrigation management with tilling practices and fertilization management.

All the above source control techniques can effectively reduce surface runoff and nutrient concentrations. Nevertheless, they cannot prevent runoff from flowing into the receiving water. The concentrations of $\mathrm{N}$ and $\mathrm{P}$ in agricultural runoff have decreased significantly by source control techniques. However, it is still difficult to achieve the safe discharge concentrations. Because long-term accumulation of nutrients in receiving waters will also increase the risk of eutrophication. Therefore, complete treatment of agricultural runoff still needs additional process control and end treatment technologies.

\section{Research progress in process control technologies}

Process control technologies aim to remove pollutants during agricultural runoff transport. Ecological ditches are engineered based on the widely distributed ditches surrounding farmlands. Before the nutrients are discharged into receiving waters, the ditches can reduce pollutants in the runoff by effectively using a similar principle to that of a surface-flow-constructed wetland [74, $75]$. They can also significantly reduce the land requisition, investment and operational costs. Therefore, this is considered a promising technology for agricultural runoff control, especially in densely populated areas. 


\section{Ecological ditch system}

An ecological ditch is an engineered system that has been developed for the removal of agricultural runoff nutrients by sorption, sedimentation, transformation, plant uptake and microbial metabolic activities [76-78]. As an important part of irrigation and drainage system, agricultural ditches are widely distributed among the farmland. Based on traditional agricultural ditches, ecological ditches are helpful to introduce substrates, aquatic plants, and interception facilities by forming a unique sediment-aquatic plant-microorganism system [79].

Periphyton is a key component of ecological ditches. It is widely distributed in natural water bodies and can help remove water pollutants by absorption, adsorption and complexation processes. Periphyton can have a large biomass and is sensitive to water quality and is effective at removing $\mathrm{N}$ and $\mathrm{P}$, among other advantages. Table 3 listed the typical ecological ditches with different vegetation and their removal capacities of nutrients. Pierobon et al. have conducted $\mathrm{N}$ removal experiments in vegetated (Phragmites australis and Typha latifolia) and unvegetated ecological ditches in the Po River Basin of Italy [80]. The results showed an average removal capacity of $1.52 \mathrm{~kg} \mathrm{~N} \mathrm{~km}^{-1}$ day $^{-1}$ in the vegetated ditches compared to the unvegetated ditches $\left(0.24 \mathrm{~kg} \mathrm{~N} \mathrm{~km}^{-1} \mathrm{day}^{-1}\right)$. This indicated that aquatic plants play a vital role in the sediment-aquatic plant-microorganism system. Vymazal and Březinová Table 3 Ecological ditches and their vegetation and
nutrients removal capacities

\begin{tabular}{|c|c|c|c|}
\hline Location & Vegetation & $\begin{array}{l}\text { Nutrients } \\
\text { removal capacity }\end{array}$ & References \\
\hline \multirow[t]{2}{*}{$\begin{array}{l}\text { Po River Basin, } \\
\text { Italy }\end{array}$} & $\begin{array}{l}\text { Phragmites aus- } \\
\text { tralis } \\
\text { Typha latifolia }\end{array}$ & $1.52 \mathrm{~kg} \mathrm{~N} /(\mathrm{km}$ day $)$ & [80] \\
\hline & Unvegetated & 0.24 kg N/(km day) & \\
\hline $\begin{array}{l}\text { South-central } \\
\text { Bohemia, } \\
\text { Czech }\end{array}$ & $\begin{array}{l}\text { Epilobium hirsutum } \\
\text { Lythrum salicaria } \\
\text { Filipendula ulmaria } \\
\text { Phragmites aus- } \\
\text { tralis } \\
\text { Typha latifolia } \\
\text { Glyceria maxima }\end{array}$ & $\begin{array}{l}5.28 \mathrm{~kg} \mathrm{~N} /(\mathrm{km} \text { day }) \\
0.70 \mathrm{~kg} \mathrm{P} /(\mathrm{km} \text { day })\end{array}$ & [81] \\
\hline Changsha, China & $\begin{array}{l}\text { Canna indica } \\
\text { Hydrocotyle } \\
\text { vulgaris } \\
\text { Sparganium } \\
\text { stoloniferum } \\
\text { Myriophyllum } \\
\text { aquaticum } \\
\text { Juncus effusus }\end{array}$ & 3.20 kg N/(km day) & [28] \\
\hline $\begin{array}{l}\text { Mississippi State, } \\
\text { USA }\end{array}$ & $\begin{array}{l}\text { Leersia oryzoides } \\
\text { Typha latifolia }\end{array}$ & $\begin{array}{l}2.19 \mathrm{~kg} \mathrm{~N} /(\mathrm{km} \text { day }) \\
0.58 \mathrm{~kg} \mathrm{P} /(\mathrm{km} \text { day })\end{array}$ & [82] \\
\hline Tianjin, China & $\begin{array}{l}\text { Iris pseudacorus } \\
\text { Lythrum salicaria }\end{array}$ & 1.73 kg N/(km day) & [83] \\
\hline
\end{tabular}

reported that a 200-m-long ecological ditch vegetated with Epilobium hirsutum, Lythrum salicaria, Filipendula ulmaria, Phragmites australis, Typha latifolia, and Glyceria maxima was used to treat the overflow from a fishpond in the Czech Republic [81]. They achieved removal capacities of $5.28 \mathrm{~kg} \mathrm{~N} \mathrm{~km}^{-1}$ day $^{-1}$ and $0.70 \mathrm{~kg} \mathrm{P} \mathrm{km}^{-1} \mathrm{day}^{-1}$. Flora and Kröger reported a drainage ditch vegetated with Leersia oryzoides and Typha latifolia in Mississippi State, USA. The nutrients removal capacities were $2.19 \mathrm{~kg} \mathrm{~N} \mathrm{~km}^{-1} \mathrm{day}^{-1}$ and $0.58 \mathrm{~kg} \mathrm{P} \mathrm{km}^{-1} \mathrm{day}^{-1}$ [82]. Li et al. studied the nitrogen removal in an ecological ditch vegetated with Iris pseudacorus and Lythrum salicaria in Tianjin, China [83]. The removal capacity of nitrogen was $1.73 \mathrm{~kg} \mathrm{~N} \mathrm{~km}^{-1}$ day $^{-1}$. These results indicated that plant diversity has a great influence on the removal capacity of ecological ditches.

Therefore, the selection of highly efficient ditch plants is also important in ecological ditch research. Tyler et al. conducted a mesocosm study on the $\mathrm{N}$ removal performance of three plant species, Leersia oryzoides, Typha latifolia, and Sparganium americanum [84]. Using a hydraulic retention time of $48 \mathrm{~h}$, TN removal efficiencies of these three plants were all higher than $50 \%$, while ammonia- $\mathrm{N}$ removal efficiencies varied from $33.68 \%$ by $S$. americanum to $59.12 \%$ by $T$. latifolia. Kumwimba et al. compared six ditch plant species (Canna indica, Acorus calamus, Cyperus alternifolius, Iris sibirica, Colocasia gigantean, and Myriophyllum verticillatum) and found that Canna indica exhibited the best performance in $\mathrm{N}$ and $\mathrm{P}$ absorption and translocation [85]. As a result, 72-99.4\% TN, 64-98.7\% TP, $75-100 \% \mathrm{NH}_{4}-\mathrm{N}$ and $100 \% \mathrm{NO}_{3}-\mathrm{N}$ were removed after treatment.

During the growing seasons, plants can accumulate large amounts of nutrients for self-growth. However, their accumulation ability reduces gradually as senescence starts [86]. Furthermore, plants decomposition will lead to the release of the retained nutrients and, thus, become another source of nutrients [87]. Harvest management is an important aspect of ecological ditch management, though it still needs more in-depth studies. The complete removal of nutrients in ecological ditches is accomplished by plant harvesting. Yu et al. studied the harvest management of an ecological ditch vegetated with Canna glauca, Hydrocotyle vulgaris, Sparganium stoloniferum, Myriophyllum verticillatum, and Juncus effuses [88]. The removal capacity of TN and TP with multiple harvesting of aboveground plant tissues was 15.74 and $2.29 \mathrm{~kg} \mathrm{a}^{-1}$, respectively. In contrast, the removal capacity of TN and TP with annual harvesting was only 4.16 and $0.34 \mathrm{~kg} \mathrm{a}^{-1}$, respectively. Therefore, timely harvesting of ecological ditch's 
aquatic plants can effectively promote nutrient removal and plant regeneration. Unfortunately, management of ecological ditches has always been a difficult problem. Large-scale harvesting requires a great deal of labor, which greatly increases the maintenance cost. Smallholders and family farming are dominant forms of agriculture in Asia and Latin America [89]. For small-scale agriculture operators, such costs are usually too high to bear. Therefore, it impedes the large-scale application of ecological ditches in these areas.

\section{Microbial treatment technologies}

Due to the low efficiency of phytoremediation, $\mathrm{N}$ and $\mathrm{P}$ removal using ecological ditches cannot be compared to municipal sewage treatment technology, especially for irrigation and during the rainfall period. Microbial treatment technologies are effective, economical, and environmentally friendly to be used widely for treatment of domestic sewage, dyeing wastewater, and animal wastewater, among others [90, 91]. Therefore, microbial technologies might be the answer for next-generation ecological ditches. Activated sludge methods involving anaerobic-anoxic-aerobic $(\mathrm{A} 2 / \mathrm{O})$ processes have been used in highly concentrated organic wastewater treatments [92]. These microorganisms can simultaneously remove nutrients (e.g., $\mathrm{N}$ and $\mathrm{P}$ ) and heavy metals (e.g., chromium and mercury) in a way that is both highly efficient and environmentally friendly [93, 94]. Wu et al. have proposed an integrated technology using both the A2/O approach and ecological ditches for treatment of heterogeneous non-point source wastewater [95]. This system could not only treat high load $\mathrm{N}$ and $\mathrm{P}$ wastewater, but also rejuvenate the ecological ditches' microbial habitat. With a hydraulic load of $200 \mathrm{~m}^{3}$ day $^{-1}$, the removal efficiencies of TP, TDP, TN, $\mathrm{NO}_{3}-\mathrm{N}$ and $\mathrm{NH}_{4}-\mathrm{N}$ reached $81 \%, 74 \%, 82 \%, 79 \%$ and $86 \%$, respectively. It will be a promising research direction to introduce microbial enhancement into traditional ecological ditches.

\section{Research progress in end treatment technologies}

Agricultural runoff end treatment is the last barrier before the nutrients enter the downstream receiving water. Constructed wetlands $(\mathrm{CW})$, buffer strips and land infiltration systems are common end treatment technologies.

$\mathrm{CW}$ is a unique system of soil-plant-microorganism. It is a transitional zone between the farmland and the receiving water, with good absorption, adsorption, and physical settlement capacity for N, P, particles and organic matter. Díaz et al. suggest that water evaporation, infiltration processes, vegetation characteristics and hydraulic retention time (HRT) are key factors affecting pollutant load concentrations in CWs [22]. Additionally, the removal efficiency of wetlands is highly seasonal. Valkama et al. studied the seasonal variation of nutrient removal efficiencies and found that TP removal efficiency was highest in June (28\%) and lowest in February (5.5\%), while TN removal efficiency was highest in July (82\%) and lowest in November (3.5\%) [96].

Like ecological ditches, CWs also rely on phytoremediation and soil absorption. CW is considered a practical end treatment technology due to its numerous advantages (e.g., low-cost, easy operation, and easy maintenance) [97] Beutel et al. reported a surface-flow constructed wetland can have a denitrification efficiency as high as $93 \%$ at 5 days hydraulic retention time (HRT) [98]. Surface-flow constructed wetland has free water surface and belongs to aerobic wetland, in which wastewater flows horizontally through the substrate surface [99]. The substrate surface formed by sediments and dead leaves of plants is the main site for denitrification. And, $\mathrm{P}$ is removed in more shallow oxidized layers. It is suitable for semi-arid environments where warm temperatures and low oxygen levels in the treatment wetland water promotes biological denitrification. The TP removal efficiency in surface-flow wetlands was $41 \%$ at 2.2 day HRT [100]. Another popular type of CW is subsurface-flow constructed wetland. Compared with the surface flow constructed wetlands, the water flows under the surface of the wetland bed, which can make full use of the biofilm growing on the surface of the packings, extend the hydraulic residence time, and improve the removal effect and capacity. Chung et al. showed a $62 \% \mathrm{TN}$ and a $52 \%$ TP removal at 5 days HRT in a subsurface-flow constructed wetland [101].

$\mathrm{CW}$ also suffers from some intrinsic drawbacks including long HRT, a large footprint, and substrate clogging. These limit its application and long-term stability. Moreover, the oxygen transfer rate may limit the nitrification process while the denitrification process may be limited by organic carbon in water [102]. TN removal in a single-stage constructed wetland is not satisfactory due to its inability to provide both aerobic and anaerobic conditions simultaneously. Vertical flow-constructed wetlands perform well in ammonia-N removal, although they are very limited in TN removal. Subsurface flowconstructed wetlands have a strong TN removal capacity, but their ability to remove ammonia- $\mathrm{N}$ is very limited. Many efforts have been made to improve CWs by using different design and operational strategies [103-105]. Sgroi et al. compared four different kinds of wetlands under the same conditions and found that free water surface wetlands have the highest denitrification efficiency, $69 \%$, while unsaturated vertical subsurface flow wetlands have the highest five-day biochemical oxygen demand 
$\left(\mathrm{BOD}_{5}\right)$, chemical oxygen demand (COD), and total oxygen demand (TOD) removal efficiencies (at 87\%, 67\% and $72 \%$, respectively) [106]. Attempts have been made to enhance CWs by introducing other proven technologies to synergistically degrade pollutants, such as membrane bio-reactors (MBR), electrochemical oxidation, and MFC. MBR technology has been combined with CWs to simultaneously improve water quality and reduce operational costs. Xiao et al. reported on an integrated system consisting of a submerged membrane bioreactor (SMBR, hollow fiber membrane) and a constructed wetland for the treatment of high load wastewater [107]. The initial concentrations of COD, TN, TP, and $\mathrm{NH}_{4}{ }^{+}$were as high as $1008.08 \mathrm{mg} \mathrm{L}^{-1}, 95.22 \mathrm{mg} \mathrm{L}^{-1}, 5.76 \mathrm{mg} \mathrm{L}^{-1}$ and $62.10 \mathrm{mg} \mathrm{L}^{-1}$, respectively. 98\% COD, 96\% TP, $80 \% \mathrm{TN}$, and $99 \% \mathrm{NH}_{4}{ }^{+}$were removed by the integrated system. Compared with CW, the SMBR contributed most of the degradation capacity, accounting for 95\% COD, 74\% TP, 68.5\% $\mathrm{TN}$ and $92 \% \mathrm{NH}_{4}{ }^{+}$[107]. This demonstrates that there is a huge gap in the contaminant degradation rate between MBR and CW. Although the combination of other proven technologies can make up for CW's shortages, they can also weaken its advantages. The management and maintenance of these combined technologies are complex with the increase in the energy demand. Furthermore, $\mathrm{CW}$ requires large land requisition, which is becoming more and more difficult, especially in densely populated area. Sensitivity of aquatic plants to temperature can result in great changes in processing efficiency among seasons. Conventional CWs demonstrate difficulty meeting efficiency requirements when confronted with continued environmental deterioration and increasingly stringent emission standards.

\section{Comprehensive control of agricultural runoff}

As listed in Table 4, various technologies have been proposed for agricultural runoff control, which can be divided into three categories. Among them, conservation tillage, fertilization management, water saving irrigation, ecological ditch, constructed wetland, and buffer strips have been successfully applied in agricultural runoff control. As mentioned above, most $\mathrm{N}$ and $\mathrm{P}$ should be removed from agricultural runoff before being discharged into receiving waters. Currently, no single technology can meet such stringent requirements. Therefore, the thorough control of agricultural runoff requires the comprehensive application of various control technologies.

To understand the status of agricultural runoff treatments comprehensively, we conducted a scenario analysis based on reference data (Table 4). Paddy soil is a typical source of agricultural runoff because rice needs a large amount of irrigation water. Thus, paddy soil was selected as the runoff source in this scenario analysis. The initial concentrations were $10 \mathrm{mg} \mathrm{N} \mathrm{L}^{-1}$ and $8 \mathrm{mg} \mathrm{P} \mathrm{L}{ }^{-1}$, respectively, and their target output concentrations were set at $0.8 \mathrm{mg} \mathrm{N} \mathrm{L}^{-1}$ and $0.06 \mathrm{mg} \mathrm{P} \mathrm{L}^{-1}$. It means that the efficiencies of denitrification and phosphorus removal should reach $92 \%$ and $99.25 \%$, respectively, as shown by the dotted line in Fig. 3. These levels are in accordance with the safe concentration thresholds of $\mathrm{TN}$ and TP in natural water [108]. According to Table 4, no-tillage, controlled-release fertilizer, ecological ditch, and surface-flow wetland are effective in nutrients removal of agricultural runoff from paddy soil. However, no control technique can achieve the target removal rate of nitrogen and phosphorus. Since they belong to source control, process control and end treatment technologies, they were assumed to be applied successively in this hypothetical farmland system. As shown in Fig. 3, the abscissa is the technique used, and the ordinate is the concentrations of nitrogen and phosphorus after the specific technique is used. For example, the application of no-tillage in paddy soil was expected to reduce TN by $8.5 \%$ and TP by $7.8 \%$ [46]. Then, the concentrations of TN and TP in agricultural runoff were expected to drop to 9.15 and $7.38 \mathrm{mg} \mathrm{L}^{-1}$, respectively. The output concentrations of TN and TP declined to a safe level only when the source control, process control, and end treatment technologies were applied comprehensively. The TN and TP concentrations in agricultural runoff decreased to 0.39 and $0.47 \mathrm{mg} \mathrm{L}^{-1}$ respectively after the successively application of no-tillage, controlled-release fertilizer, ecological ditch and surface-flow constructed wetland [46, 65, 85, 106]. Among these methods, controlled-release fertilizers contributed the most. Coupled with no-tillage, source control technologies played a vital role in agricultural runoff control, which contributed to more than $60 \%$ of the $\mathrm{N}$ and $\mathrm{P}$ reduction. In addition, water saving irrigation can effectively reduce runoff volume to facilitate the reduction of nutrient loads. Ecological ditches served as the connection channel between the farmland and the receiving water. Their natural advantages made full use of the runoff transport time to complete the $\mathrm{N}$ and $\mathrm{P}$ removal and contributed to $26.4 \% \mathrm{~N}$ and $21.8 \% \mathrm{P}$ removal. After source and process control, the concentrations of $\mathrm{N}$ and $\mathrm{P}$ were reduced to 1.02 and $0.98 \mathrm{mg} \mathrm{L}^{-1}$ respectively. These concentrations were very close to the targeted concentrations and indicated that agricultural runoff can be controlled with use of source and process control methods. For countries with limited arable land, this strategy would minimize the amount of land occupied for mitigation techniques.

Scenario analysis in this review was conducted under ideal conditions and without consideration of coupling effects between the different technologies. It still provides a comprehensive understanding of agricultural 
Table 4 Current practices on $\mathbf{N}$ and $\mathrm{P}$ control from agricultural runoff

\begin{tabular}{|c|c|c|c|c|c|c|c|c|}
\hline Number & Strategy & Category & Technology & Source & $\begin{array}{l}\text { Runoff decrease } \\
(\%)\end{array}$ & $\begin{array}{l}\text { TN } \\
\text { decrease } \\
(\%)\end{array}$ & TP decrease (\%) & References \\
\hline 1 & \multirow[t]{12}{*}{ Source control } & \multirow[t]{4}{*}{ Conservation } & Reduced & Cropland & 64 & 7.7 & - & {$[45]$} \\
\hline 2 & & & No-tillage & Paddy soil & 25.9 & 8.5 & 7.8 & {$[46]$} \\
\hline 3 & & & SPG cover & Cabbage field & 29.4 & 34.7 & 7.8 & {$[49]$} \\
\hline 4 & & & Amendment & Tropical soil & 16.8 & 41.8 & 39.1 & {$[50]$} \\
\hline 5 & & Rotation tillage & Rotation tillage & Canadian prairies & - & 60 & 38 & {$[54]$} \\
\hline 6 & & \multirow{6}{*}{$\begin{array}{l}\text { Fertilization man- } \\
\text { agement }\end{array}$} & & Orchard & - & 36.2 & 31.4 & {$[62]$} \\
\hline 7 & & & Band placement & Nursery land & - & 61.2 & 68.1 & {$[60]$} \\
\hline 8 & & & Hole placement & Nursery land & - & 65.1 & 67.9 & {$[61]$} \\
\hline 9 & & & $\begin{array}{l}\text { Controlled- } \\
\text { release N }\end{array}$ & Wheat-maize & - & 30.5 & - & {$[64]$} \\
\hline 10 & & & $\begin{array}{l}\text { Controlled- } \\
\text { release }\end{array}$ & $\begin{array}{l}\text { rotation Corn } \\
\text { land }\end{array}$ & - & 27.8 & 34 & {$[65]$} \\
\hline 11 & & & $\begin{array}{l}\text { Controlled- } \\
\text { release }\end{array}$ & Paddy soil & & & & {$[66]$} \\
\hline $\begin{array}{l}12 \\
13\end{array}$ & & $\begin{array}{l}\text { Water saving } \\
\text { irrigation }\end{array}$ & $\begin{array}{l}\text { Alternate wetting } \\
\text { and drying }\end{array}$ & Paddy soil & $30.2 \sim 36.7$ & - & - & {$[73]$} \\
\hline $\begin{array}{l}14 \\
15\end{array}$ & \multirow[t]{2}{*}{ Process control } & Ecological ditch & Ecological ditch & Paddy soil & - & 72 & 64 & {$[85]$} \\
\hline 16 & & $\begin{array}{l}\text { Microbial treat- } \\
\text { ment }\end{array}$ & $\begin{array}{l}\mathrm{A}^{2} / O \text { with Eco- } \\
\text { ditch }\end{array}$ & Suburban & - & 82 & 81 & [95] \\
\hline 17 & \multirow[t]{6}{*}{ End treatment } & & $\begin{array}{l}\text { Surface-flow } \\
\text { wetland }\end{array}$ & $\begin{array}{l}\text { Agricultural } \\
\text { runoff }\end{array}$ & - & 60 & - & {$[98]$} \\
\hline 18 & & & $\begin{array}{l}\text { Surface-flow } \\
\text { wetland }\end{array}$ & $\begin{array}{l}\text { Agricultural } \\
\text { runoff }\end{array}$ & - & - & 41 & [100] \\
\hline 19 & & & $\begin{array}{l}\text { Subsurface-flow } \\
\text { wetland }\end{array}$ & Urban & - & 62 & 52 & {$[106]$} \\
\hline \multicolumn{8}{|l|}{20} & \\
\hline 21 & & Buffer strips & $\begin{array}{l}\text { Integrated buffer } \\
\text { zone }\end{array}$ & $\begin{array}{l}\text { Agricultural } \\
\text { runoff }\end{array}$ & - & 39 & 50 & [112] \\
\hline 22 & & & $\begin{array}{l}\text { Vegetated buffer } \\
\text { strips }\end{array}$ & Maize field & - & 52 & - & [113] \\
\hline
\end{tabular}

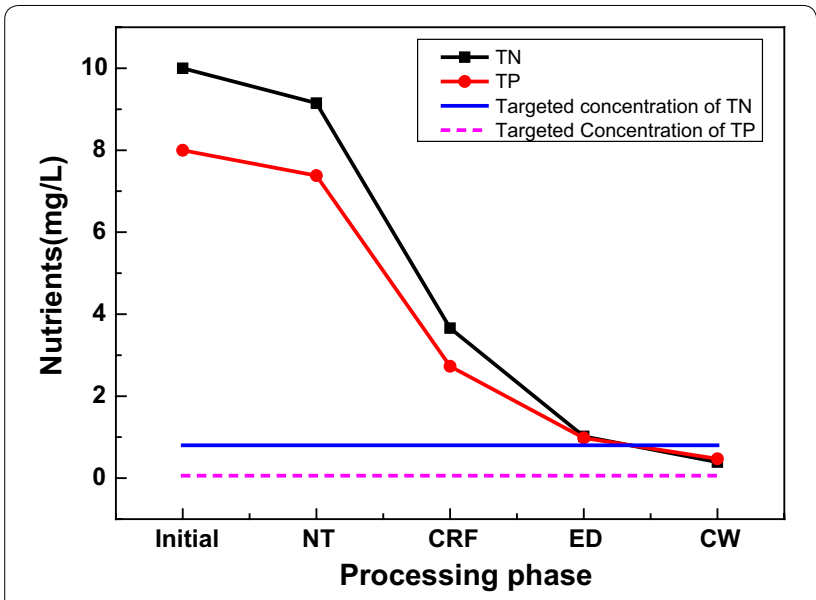

Fig. 3 Scenario analysis of integrated treatment of agricultural runoff $[46,65,85,106]$ (NT: no-tillage; CRF: controlled-release fertilizer; ED: ecological ditch; CW: constructed wetland) runoff control, however. Since agricultural runoff characteristics vary temporally and spatially based on rainfall and irrigation events [109], the runoff treatment system's removal efficiency also varies based on flow and concentration. The processing load of control and end treatment methods should be designed to meet peak processing requirements.

Nowadays, researchers have proposed a variety of effective agricultural runoff control techniques from different perspectives. But, neither technology can do the job of controlling agricultural runoff. This review identifies the spatial location of these technologies and their processing capabilities. Aiming at the control of N and P, this review makes full use of the space of farmland system and tries to realize the control of agricultural runoff through the comprehensive application of various technologies based on existing technologies. The ideal treatment technology for agricultural runoff should have 
the following characteristics: (1) adaptability for local conditions including climate, geography, type of crops, planting 448 scale, agricultural facilities, and farmer education; (2) simplicity for management without complex operating procedures or technical specifications; (3) low investment and operational costs; (4) flexibility to accommodate big fluctuations in water volume and pollutant concentrations; (5) processability with comprehensive degradation capacities for nutrients and organic matter. To date, no existing technology can satisfy all these conditions.

Based on current technologies, integrated schemes of two or more are considered effective. Source control technologies can decrease both water volume and pollution load through tillage management, fertilization management, and water saving irrigation. They can be well popularized via government administrations. The subsequent processing load will be greatly alleviated after source control. Process control technologies such as ecological ditches can supplement source control technologies. CW has been proven as an effective method for end control in the past. However, confronted with the continual deterioration of the environment and increasingly stringent emission standards, CW systems operating as standalone technologies will have difficulty meeting new environmental requirements. Research is now focused on hybrid CWs, and it may be used in future as an improved method for existing constructed wetlands. Building new constructed wetlands is becoming increasingly difficult due to arable land shortages. Thus, further efforts to develop process control technologies are needed.

\section{Acknowledgements}

This work was carried out with the support of "Cooperative Research Program for Agriculture Science and Technology Development (Effects of plastic mulch wastes on crop productivity and agro-environment, Project No. PJ01475801)" Rural Development Administration, Republic of Korea.

\section{Authors' contributions \\ XY performed and supported the analysis of technologies for agricultural non-point source pollution control. NG supported data analysis and statistical evaluation. MZ, DCWT, DL, LZ, ADI, PDD, XY and JR contributed in writing and formatting the manuscript. YSO mainly supervised the current study as cor- responding author. All authors read and approved the final manuscript.}

\section{Funding}

Cooperative Research Program for Agriculture Science and Technology Development (Effects of plastic mulch wastes on crop productivity and agroenvironment, Project No.PJ01475801)" Rural Development Administration, Republic of Korea.

\section{Availability of data and materials}

All data generated or analyzed during this study are included in this published article and its supplementary information files. References are included for each and every data gathered from the published articles.

\section{Competing interests}

The authors declare that they have no competing interests.

\section{Author details}

${ }^{1}$ College of Water Conservancy and Environmental Engineering, Zhejiang University of Water Resources and Electric Power, Hangzhou 310018, China.

${ }^{2}$ Korea Biochar Research Center \& Division of Environmental Science and Ecological Engineering, Korea University, Seoul, Republic of Korea. ${ }^{3}$ Department of Environmental Engineering, China Jiliang University, Hangzhou 310018, China. ${ }^{4}$ Department of Civil and Environmental Engineering, Hong Kong Polytechnic University, Hung Hom, Kowloon, Hong Kong, China. ${ }^{5}$ School of Architecture and Civil Engineering, Institute of Foundation Engineering, Water- and Waste-Management, Soil-and Groundwater-Management, University of Wuppertal, Pauluskirchstraße 7, 42285 Wuppertal, Germany. ${ }^{6}$ Department of Environment, Energy and Geoinformatics, University of Sejong, 98 Gunja-Dong, Guangjin-Gu, Seoul, Republic of Korea.

Received: 17 November 2019 Accepted: 18 January 2020

Published online: 04 February 2020

\section{References}

1. Evans AE, Mateo-Sagasta J, Qadir M, Boelee E, Ippolito A (2019) Agricultural water pollution: key knowledge gaps and research needs. Curr Opin Environ Sustain 36:20-27

2. Thatai S, Verma R, Khurana P, Goel P, Kumar D (2019) Water quality standards, its pollution and treatment methods. A new generation material graphene: applications in water technology. Springer International Publishing, Cham, pp 21-42

3. Walker DB, Baumgartner DJ, Gerba CP, Fitzsimmons K (2019) Surface water pollution. In: Brusseau ML, Pepper IL, Gerba CP (eds) Environmental and pollution science, 3rd edn. Elsevier, pp 261-292

4. Crini G, Lichtfouse E (2019) Advantages and disadvantages of techniques used for wastewater treatment. Environ Chem Lett 17:145-155

5. Crini G, Lichtfouse E, Wilson LD, Morin-Crini N (2019) Conventional and non-conventional adsorbents for wastewater treatment. Environ Chem Lett 17:195-213

6. Gerba CP, Pepper IL (2019) Municipal wastewater treatment. In: Brusseau ML, Pepper IL, Gerba CP (eds) Environmental and pollution science, 3rd edn. Elsevier, pp 393-418

7. Singh NK, Gupta G, Upadhyay AK, Rai UN (2019) Biological wastewater Treatment for prevention of river water pollution and reuse: perspectives and challenges. Water conservation, recycling and reuse: issues and challenges. Springer Singapore, Singapore, pp 81-93

8. Li C, Wang Y, Ye C, Wei W, Zheng B, Xu B (2019) A proposed delineation method for lake buffer zones in watersheds dominated by non-point source pollution. Sci Total Environ 660:32-39

9. Wang H, He P, Shen C, Wu Z (2019) Effect of irrigation amount and fertilization on agriculture non-point source pollution in the paddy field. Environ Sci Pollut Res 26:10363-10373

10. Zhang T, Yang Y, Ni J, Xie D (2019) Adoption behavior of cleaner production techniques to control agricultural non-point source pollution: a case study in the three Gorges Reservoir Area. J Clean Prod 223:897-906

11. Zhang WL, Wu SX, Ji HJ, Kolbe H (2004) Estimation of agricultural non-point source pollution in China and the alleviating strategies I. Estimation of agricultural non-point source pollution in China in early 21 century. Sci Agric Sin 37:1008-1017

12. Vighi M, Chiaudani G (1987) Eutrophication in Europe: the role of agricultural activities. Rev Environ Toxicol 3:213-257

13. Jabbar FK, Grote K (2019) Statistical assessment of nonpoint source pollution in agricultural watersheds in the Lower Grand River watershed, MO, USA. Environ Sci Pollut Res 26:1487-1506

14. Wang M, Zhang D, Dong J, Tan SK (2018) Application of constructed wetlands for treating agricultural runoff and agro-industrial wastewater: a review. Hydrobiologia 805:1-31

15. Conley DJ, Paerl HW, Howarth RW, Boesch DF, Seitzinger SP, Havens KE, Lancelot C, Likens GE (2009) Controlling eutrophication: nitrogen and phosphorus. Science 323:1014-1015

16. Guo L (2007) Doing battle with the green monster of Taihu Lake. Science $317: 1166$ 
17. Qin Y, Li G, Gao Y, Zhang L, Ok YS, An T (2018) Persistent free radicals in carbon-based materials on transformation of refractory organic contaminants (ROCs) in water: a critical review. Water Res 137:130-143

18. Peigné J, Ball BC, Roger-Estrade J, David C (2007) Is conservation tillage suitable for organic farming? A review. Soil Use Manage 23(2):129-144

19. Chilundo M, Joel A, Wesstrom I, Brito R, Messing I (2018) Influence of irrigation and fertilisation management on the seasonal distribution of water and nitrogen in a semi-arid loamy sandy soil. Agr Water Manage 199:120-137

20. Kettering J, Ruidisch M, Gaviria C, Ok YS, Kuzyakov Y (2013) Fate of fertilizer $15 \mathrm{~N}$ in intensive ridge cultivation with plastic mulching under a monsoon climate. Nutr Cycl Agroecosyst 95:57-72

21. Wu M, Tang X, Li Q, Yang W, Feng J, Tang M, Scholz M (2013) Review of ecological engineering solutions for rural non-point source water pollution control in hubei province, china. Water Air Soil Poll 224(5):1561

22. Díaz FJ, Geen AT, Dahlgren RA (2012) Agricultural pollutant removal by constructed wetlands: implications for water management and design. Agr Water Manage 104:171-183

23. Cordell D, Drangert JO, White S (2009) The story of phosphorus: global food security and food for thought. Glob Environ Chang 19:292-305

24. Carvalho FP (2006) Agriculture, pesticides, food security and food safety. Environ Sci Policy 9:685-692

25. Huang J, Xu C, Ridoutt BG, Wang X, Ren P (2017) Nitrogen and phosphorus losses and eutrophication potential associated with fertilizer application to cropland in China. J Clean Prod 159:171-179

26. Zhang WF, Dou ZX, He P, Ju XT, Powlson D, Chadwick D, Norse D, Lu YL, Zhang Y, Wu L, Chen XP, Cassman KG, Zhang FS (2013) New technologies reduce greenhouse gas emissions from nitrogenous fertilizer in China. Proc Natl Acad Sci U S A 110:8375-8380

27. Mandal S, Sarkar B, Bolan N, Novak J, Ok YS, Van Zwieten L, Singh BP, Kirkham MB, Choppala G, Spokas K, Naidu R (2016) Designing advanced biochar products for maximizing greenhouse gas mitigation potential. Crit Rev Env Sci Tec 46(17):1367-1401

28. Chen L, Liu F, Wang Y, Li X, Zhang S, Li Y, Wu J (2015) Nitrogen removal in an ecological ditch receiving agricultural drainage in subtropical central China. Ecol Eng 82:487-492

29. Cookson WR, Rowarth JS, Cameron KC (2000) The effect of autumn applied $15 \mathrm{~N}$-labelled fertilizer on nitrate leaching in a cultivated soil during winter. Nutr Cycl Agroecosys 56:99-107

30. Harmel RD, Smith DR, Haney RL, Dozier M (2009) Nitrogen and phosphorus runoff from cropland and pasture fields fertilized with poultry litter. J Soil Water Conserv 64:400-412

31. Zhang LJ, Ma YH, Shi YY, Zhu XH, Wang LT, Ma ZW, Fang RY (2011) Effects of irrigation and fertilization on nitrogen and phosphorus runoff from paddy field. J Soil Water Conserv 25:7-12 (in Chinese)

32. Gao C, Zhu J, Zhu J, Hosen Y, Wang D, Zhou J, Gao X, Dou Y (2005) Phosphorus exports via overland runoff under different land uses and their seasonal pattern. Acta Sci Circum 25:1543-1549

33. Carpenter SR, Caraco NF, Correll DL, Howarth RW, Sharpley AN, Smith VH (1998) Nonpoint pollution of surface waters with phosphorus and nitrogen. Ecol Appl 8:559-568

34. Smith VH (2003) Eutrophication of freshwater and coastal marine ecosystems a global problem. Environ Sci Pollut Res 10:126-139

35. Sun B, Zhang L, Yang L, Zhang F, Norse D, Zhu Z (2012) Agricultural non-point source pollution in China: causes and mitigation measures. Ambio 41:370-379

36. Tiessen KH, Elliott JA, Yarotski J, Lobb DA, Flaten DN, Glozier NE (2010) Conventional and conservation tillage: influence on seasonal runoff, sediment, and nutrient losses in the Canadian Prairies. J Environ Qual 39:964-980

37. Blankenberg AGB, Haarstad K, Paruch AM (2015) Agricultural runoff in Norway: the problem, the regulations, and the role of wetlands. In: Vymazal J (ed) The role of natural and constructed wetlands in nutrient cycling and retention on the landscape. Springer, Cham.

38. Awad YM, Wang J, Igalavithana AD, Tsang DCW, Kim K-H, Lee SS, Ok YS (2018) Biochar Effects on Rice Paddy: Meta-analysis. In: Sparks DL (ed) Advances in Agronomy. Academic Press, Cambridge, pp 1-32
39. Al-Wabel Ml, Hussain Q, Usman ARA, Ahmad M, Abduljabbar A, Sallam AS, Ok YS (2018) Impact of biochar properties on soil conditions and agricultural sustainability: a review. Land Degrad Dev 29:2124-2161

40. Arnhold S, Lindner S, Lee B, Martin E, Kettering J, Nguyen TT, Koellner T, OkYS, Huwe B (2014) Conventional and organic farming: Soil erosion and conservation potential for row crop cultivation. Geoderma 219-220:89-105

41. Lee SS, Chang SX, Chang Y-Y, Ok YS (2013) Commercial versus synthesized polymers for soil erosion control and growth of Chinese cabbage. SpringerPlus 2:534

42. Holland JM (2004) The environmental consequences of adopting conservation tillage in Europe: reviewing the evidence. Agr Ecosyst Environ 103:1-25

43. Plaza-Bonilla D, Cantero-Martínez C, Viñas P, Álvaro-Fuentes J (2013) Soil aggregation and organic carbon protection in a no-tillage chronosequence under Mediterranean conditions. Geoderma 193-194:76-82

44. Schmidt JH, Junge S, Finckh MR (2019) Cover crops and compost prevent weed seed bank buildup in herbicide-free wheat-potato rotations under conservation tillage. Ecol Evol 9:2715-2724

45. Clausen JC, Jokela WE, Potter FI, Williams JW (1996) Paired watershed comparison of tillage effects on runoff, sediment, and pesticide losses. J Environ Qual 25:1000-1007

46. Liang X, Wang Z, Zhang Y, Zhu C, Lin L, Xu L (2016) No-tillage effects on $\mathrm{N}$ and $\mathrm{P}$ exports across a rice-planted watershed. Environ Sci Pollut Res 23:8598-8609

47. Awad YM, Blagodatskaya E, Ok YS, Kuzyakov Y (2012) Effects of polyacrylamide, biopolymer, and biochar on decomposition of soil organic matter and plant residues as determined by $14 \mathrm{c}$ and enzyme activities. Eur J Soil Biol 48: 1-10.

48. Meier S, Curaqueo G, Khan N, Bolan N, Cea M, Eugenia GM, Cornejo P, Ok YS, Borie F (2017) Chicken-manure-derived biochar reduced bioavailability of copper in a contaminated soil. J Soils Sediments 17:741-750

49. Won C, Shin M, Lee S, Park Y, Lee Y, Shin Y, Choi J (2016) NPS pollution reduction from Alpine fields using surface cover material and soil amendments. Irrig Drain 65:193-199

50. Lee SS, Shah HS, Awad YM, Kumar S, Ok YS (2015) Synergy effects of biochar and polyacrylamide on plants growth and soil erosion control. Environ Earth Sci 74:2463-2473

51. Lee CH, Wang CC, Lin HH, Lee SS, Tsang DCW, Jien SH, Ok YS (2018) In-situ biochar application conserves nutrients while simultaneously mitigating runoff and erosion of an Fe-oxide-enriched tropical soil. Sci Total Environ 619-620:665-671

52. Sun YQ, Chen SS, Lau AYT, Tsang DCW, Mohanty SK, Bhatnagar A, Rinklebe J, Lin KY, OkYS (2020) Waste-derived compost and biochar amendments for stormwater treatment in bioretention column: Cotransport of metals and colloids. J Hazard Mater 383: 121243.

53. Prenarathna KSD, Rajapaksha AU, Sarkar B, Kwon EE, Bhatnagar A, Ok YS, Vithanage M (2019) Biochar-based engineered composites for sorptive decontamination of water: a review. Chem Eng J 372:536-550

54. Liu K, Elliott JA, Lobb DA, Flaten DN, Yarotski J (2014) Conversion of conservation tillage to rotational tillage to reduce phosphorus losses during snowmelt runoff in the Canadian Prairies. J Environ Qual 43:1679-1689

55. Daverede IC, Kravchenko AN, Hoeft RG, Nafziger ED, Bullock DG, Warren JJ, Gonzini LC (2015) Phosphorus runoff: impact of tillage and soil phosphorus levels. J Environ Qual 32:1436-1444

56. Malhi SS, Grant CA, Johnston AM, Gill KS (2001) Nitrogen fertilization management for no-till cereal production in the Canadian Great Plains: a review. Soil Till Res 60:101-122

57. Peng S, Buresh RJ, Huang J, Zhong X, Zou Y, Yang J, Wang G, Liu Y, Hu R, Tang Q (2010) Improving nitrogen fertilization in rice by sitespecific N management. A review. Agron Sustain Dev 30:649-656

58. Cassman KG, Dobermann A, Walters DT (2002) Agroecosystems, nitrogen-use efficiency, and nitrogen management. Ambio 31:132-141

59. Yao Y, Zhang M, Tian Y, Zhao M, Zhang B, Zeng K, Zhao M, Yin B (2018) Urea deep placement in combination with Azolla for reducing nitrogen loss and improving fertilizer nitrogen recovery in rice field. Field Crop Res 218:141-149 
60. Liao M, Zhaojin YE, Huang Y, Ting L, Shen J, Zhang Y (2017) Influence of different fertilization management modes on phosphorus loss in run-off from nursery land in the catchment area of Hexi reservoir in Changxing county. Acta Ecol Sin 37:7342-7350

61. Ye ZJ, Liao M, Huang Y, Ting L, Shen J, Zhang Y (2016) Influence of different management mode of fertilization on nitrogen losses in runoff from nursery land in a catchment area. J Soil Water Conserv 30:30-37

62. Zeng SC, Su ZY, Chen BG, Wu QT, Ouyang Y (2008) Nitrogen and phosphorus runoff losses from orchard soils in South China as affected by fertilization depths and rates. Pedosphere 18:45-53

63. Irfan SA, Razali R, KuShaari K, Mansor N, Azeem B, Ford Versypt AN (2018) A review of mathematical modeling and simulation of controlled-release fertilizers. J Control Release 271:45-54

64. Tan D, Jiang L, Tan S, Zheng F, Xu Y, Cui R, Wang M, Shi J, Li G, Liu Z (2013) An in situ study of inorganic nitrogen flow under different fertilization treatments on a wheat-maize rotation system surrounding Nansi Lake, China. Agr Water Manage 123:45-54

65. Kun LI (2012) Effects of controlled release fertilizer on loss of nitrogen and phosphorus from farmland. J Anhui Agr Sci 40:12466-12470

66. Hua L, Liu J, Zhai L, Xi B, Zhang F, Wang H, Liu H, Chen A, Fu B (2017) Risks of phosphorus runoff losses from five Chinese paddy soils under conventional management practices. Agr Ecosyst Environ 245:112-123

67. Zeng M, Vries WD, Bonten LTC, Zhu Q, Hao T, Liu X, Xu M, Shi X, Zhang F, Shen J (2017) Model-based analysis of the long-term effects of fertilization management on cropland soil acidification. Environ Sci Technol 51:3843-3851

68. Zhao X, Zhou Y, Min J, Wang S, Shi W, Xing G (2012) Nitrogen runoff dominates water nitrogen pollution from rice-wheat rotation in the Taihu Lake region of China. Agr Ecosyst Environ 156:1-11

69. Aziz O, Hussain S, Rizwan M, Riaz M, Bashir S, Lin L, Mehmood S, Imran M, Yaseen R, Lu G (2018) Increasing water productivity, nitrogen economy, and grain yield of rice by water saving irrigation and fertilizer-N management. Environ Sci Pollut Res 25:16601-16615

70. Hao Z, Xue YG, Wang ZQ, Yang JC, Zhang JH (2009) An alternate wetting and moderate soil drying regime improves root and shoot growth in rice. Crop Sci 49:2246-2260

71. Matsuo N, Mochizuki T (2009) Growth and yield of six rice cultivars under three water-saving cultivations. Plant Prod Sci 12:514-525

72. Yang J, Huang D, Duan H, Tan G, Zhang J (2009) Alternate wetting and moderate soil drying increases grain yield and reduces cadmium accumulation in rice grains. J Sci Food Agric 89(10):1728-1736

73. Liang XQ, Chen YX, Nie ZY, Ye YS, Liu J, Tian GM, Wang GH, Tuong TP (2013) Mitigation of nutrient losses via surface runoff from rice cropping systems with alternate wetting and drying irrigation and site-specific nutrient management practices. Environ Sci Pollut Res 20(10):6980-6991

74. Bulc TG, Klemencic AK, Razinger J (2011) Vegetated ditches for treatment of surface water with highly fluctuating water regime. Water Sci Technol 63(10):2353

75. Moeder M, Carranzadiaz O, Lópezangulo G, Vegaaviña R, Chávezdurán FA, Jomaa S, Winkler U, Schrader S, Reemtsma T, Delgadovargas F (2017) Potential of vegetated ditches to manage organic pollutants derived from agricultural runoff and domestic sewage: a case study in Sinaloa (Mexico). Sci Total Environ 598:1106-1115

76. Dollinger J, Dagès C, Bailly J-S, Lagacherie P, Voltz M (2015) Managing ditches for agroecological engineering of landscape A review. Agron Sustain Dev 35(3):999-1020

77. Kumwimba MN, Dzakpasu M, Zhu B, Wang T, llunga L, Kavidia Muyembe D (2017) Nutrient removal in a trapezoidal vegetated drainage ditch used to treat primary domestic sewage in a small catchment of the upper Yangtze River. Water Environ J 31:72-79

78. Zhao S, Cui Y, Luo Y, Li P, Zhao S, Cui Y, Luo Y, Li P (2017) Experimental study on wetland hydraulic characteristics of vegetated drainage ditches. Water 9:311

79. Kumwimba MN, Meng F, Iseyemi O, Moore MT, Zhu B, Tao W, Liang TJ, llunga L (2018) Removal of non-point source pollutants from domestic sewage and agricultural runoff by vegetated drainage ditches (VDDs): design, mechanism, management strategies, and future directions. Sci Total Environ 639:742-759
80. Pierobon E, Castaldelli G, Mantovani S, Vincenzi F, Fano EA (2013) Nitrogen removal in vegetated and unvegetated drainage ditches impacted by diffuse and point sources of pollution. Clean-Soil Air Water 41(1):24-31

81. Vymazal J, Březinová TD (2018) Removal of nutrients, organics and suspended solids in vegetated agricultural drainage ditch. Ecol Eng 118:97-103

82. Flora C, Kröger R (2014) Use of vegetated drainage ditches and lowgrade weirs for aquaculture effluent mitigation: I Nutrients. Aquacult Eng 60:56-62

83. Li S, Wang X, Tu J, Qiao B, Li J (2016) Nitrogen removal in an ecological ditch based on an orthogonal test. Water Air Soil Poll 227:396

84. Tyler HL, Moore MT, Locke MA (2012) Influence of three aquatic macrophytes on mitigation of nitrogen species from agricultural runoff. Water Air Soil Poll 223:3227-3236

85. Kumwimba MN, Dzakpasu M, Zhu B, Muyembe DK (2016) uptake and release of sequestered nutrient in subtropical monsoon ecological ditch plant species. Water Air Soil Poll 227:396-427

86. Menon R, Holland MM (2014) Phosphorus release due to decomposition of wetland plants. Wetlands 34(6):1191-1196

87. Kröger R, Holland MM, Moore MT, Cooper CM (2007) Hydrological variability and agricultural drainage ditch inorganic nitrogen reduction capacity. J Environ Qual 36(6):1646-1652

88. Yu H, Yang ZJ, Xiao RL, Zhang SN, Liu F, Xiang ZX (2013) Absorption capacity of nitrogen and phosphorus of aquatic plants and harvest management research. Acta Prataculturae Sinica 22:294-299

89. Thapa G (2010) Smallholder or family farming in transforming economies of Asia \& Latin America: challenges and opportunities. paper presented at the international Conference on dynamics of rural transformation in emerging economies. New Delhi.

90. Fernandes H, Jungles MK, Hoffmann H, Antonio RV, Costa RH (2013) Full-scale sequencing batch reactor (SBR) for domestic wastewater: performance and diversity of microbial communities. Bioresour Technol 132:262-268

91. Wu H, Wang S, Kong H, Liu T, Xia M (2007) Performance of combined process of anoxic baffled reactor-biological contact oxidation treating printing and dyeing wastewater. Bioresour Technol 98:1501-1504

92. Kassab G, Halalsheh M, Klapwijk A, Fayyad M, Lier JBV (2010) Sequential anaerobic-aerobic treatment for domestic wastewater - a review. Bioresour Technol 101:3299-3310

93. Samaras P, Papadimitriou CA, Vavoulidou D, Yiangou M, Sakellaropoulos GP (2009) Effect of hexavalent chromium on the activated sludge process and on the sludge protozoan community. Bioresour Technol 100:38-43

94. Ying C, Umetsu K, Ihara I, Sakai Y, Yamashiro T (2010) Simultaneous removal of organic matter and nitrogen from milking parlor wastewater by a magnetic activated sludge (MAS) process. Bioresour Technol 101:4349-4353

95. Wu Y, Hu Z, Yang L, Graham B, Kerr PG (2011) The removal of nutrients from non-point source wastewater by a hybrid bioreactor. Bioresour Technol 102:2419-2426

96. Valkama P, Mäkinen E, Ojala A, Vahtera H, Lahti K, Rantakokko K, Vasander H, Nikinmaa E, Wahlroos O (2017) Seasonal variation in nutrient removal efficiency of a boreal wetland detected by high-frequency on-line monitoring. Ecol Eng 98:307-317

97. Wu H, Zhang J, Ngo HH, Guo W, Hu Z, Liang S, Fan J, Liu H (2015) A review on the sustainability of constructed wetlands for wastewater treatment: design and operation. Bioresour Technol 175:594-601

98. Beutel MW, Newton CD, Brouillard ES, Watts RJ (2009) Nitrate removal in surface-flow constructed wetlands treating dilute agricultural runoff in the lower Yakima Basin, Washington. Ecol Eng 35:1538-1546

99. Kasak K, Truu J, Ostonen I, Jürgen Sarjas Truu M (2018) Biochar enhances plant growth and nutrient removal in horizontal subsurface flow constructed wetlands. Sci Total Environ 639:67-74

100. Yates CR, Prasher SO (2009) Phosphorus reduction from agricultural runoff in a pilot-scale surface-flow constructed wetland. Ecol Eng 35:1693-1701

101. Chung AKC, Wu Y, Tam NFY, Wong MH (2008) Nitrogen and phosphate mass balance in a sub-surface flow constructed wetland for treating municipal wastewater. Ecol Eng 32:81-89 
102. Wu S, Kuschk P, Brix H, Vymazal J, Dong R (2014) Development of constructed wetlands in performance intensifications for wastewater treatment: a nitrogen and organic matter targeted review. Water Res 57:40-55

103. Foladori P, Ruaben J, Ortigara ARC, Andreottola G (2014) Batch feed and intermittent recirculation to increase removed loads in a vertical subsurface flow filter. Ecol Eng 70:124-132

104. Garcia J, Rousseau D, Morato J, Lesage E, Matamoros V, Bayona J (2010) Contaminant removal processes in subsurface-flow constructed wetlands: a review. Crit Rev Env Sci Tec 40(7):561-661

105. Imfeld G, Braeckevelt M, Kuschk P, Richnow HH (2009) Monitoring and assessing processes of organic chemicals removal in constructed wetlands. Chemosphere 74:349-362

106. Sgroi M, Pelissari C, Roccaro P (2018) Removal of organic carbon, nitrogen, emerging contaminants and fluorescing organic matter in different constructed wetland configurations. Chem Eng J 332:619-627

107. Xiao ER, Wei L, Feng H, Cheng SP, Wu ZB (2010) Performance of the combined SMBR-IVCW system for wastewater treatment. Desalination 250:781-786

108. Xu H, Paerl HW, Qin B, Zhu G, Hall NS, Wu Y (2015) Determining critical nutrient thresholds needed to control harmful cyanobacterial blooms in eutrophic Lake Taihu. China. Environ Sci Technol 49(2):1051-1059
109. Kovacic DA, David MB, Gentry LE, Starks KM, Cooke RA (2000) Effectiveness of constructed wetlands in reducing nitrogen and phosphorus export from agricultural tile drainage. J Environ Qual 29:1262-1274

110. Fujihara S, Sasaki H, Aoyagi Y, Sugahara T (2008) Nitrogen-to-protein conversion factors for some cereal products in Japan. J Food Sci 73:C204-209

111. Stevenson FJ, Keeney DR (1982) Nitrogen management for maximum efficiency and minimum pollution. Agronomy 22:605-649

112. Zak D, Kronvang B, Carstensen MV, Hoffmann CC, Kjeldgaard A, Larsen SE, Audet J, Egemose S, Jorgensen CA, Feuerbach P, Gertz F, Jensen HS (2018) Nitrogen and phosphorus removal from agricultural runoff in integrated buffer zones. Environ Sci Technol 52(11):6508-6517

113. Salazar O, Rojas C, Avendaño F, Realini P, Nájera F, Tapia Y (2015) Inorganic nitrogen losses from irrigated maize fields with narrow buffer strips. Nutr Cycl Agroecosys 102:359-370

\section{Publisher's Note}

Springer Nature remains neutral with regard to jurisdictional claims in published maps and institutional affiliations.

\section{Submit your manuscript to a SpringerOpen ${ }^{\odot}$ journal and benefit from:}

- Convenient online submission

- Rigorous peer review

- Open access: articles freely available online

- High visibility within the field

- Retaining the copyright to your article

Submit your next manuscript at $\boldsymbol{\nabla}$ springeropen.com 